\title{
Mutual Recognition and its Implications for the Gathering of Evidence in Criminal proceedings: a Critical Analysis of the Initiative for a European Investigation Order
}

\author{
Frank Zimmermann, Sanja Glaser, Andreas Motz ${ }^{\star}$
}

\begin{abstract}
The authors examine the development of cooperation in criminal matters within the European Union with a special view to the gathering of evidence and the proposed directive for a European Investigation Order (EIO). First, they analyse the legitimacy of the mutual recognition of judicial decisions in criminal matters. Then they describe the most characteristic features of the framework decisions on the mutual recognition of freezing orders and the European Evidence Warrant. On this basis, they scrutinise the initiative for an EIO in a third step. Although they come to the conclusion that the initiative largely avoids forum shopping and leaves the executing Member State more discretion in the implementation of an EIO than previous instruments have done, they criticise that specific prerequisites of coercive measures could lose their effect (e.g. the requirement of previous judicial authorisation). Furthermore they call for additional grounds for refusal in order to improve the foreseeability of criminal prosecution, e.g. the double criminality requirement or a territoriality reservation.
\end{abstract}

\section{Introduction}

On 29 April 2010 seven EU Member States launched an initiative for a directive on the European Investigation Order (EIO). ${ }^{1}$ If successful, it would be another important step towards the full implementation of the principle of mutual recognition in criminal matters. This contribution takes into account the development until March 2011. Since the time when the text was originally drafted for the THEMIS competition organised by the European Judicial Training Network in 2010, various amendments have been discussed - and the debate still continues. Nevertheless the negotiations have reached a stage at which it should be possible to foresee the characteristics of the new instrument with sufficient clarity and assess its implications. Apart from that, the analysis of the proposal for an EIO shall also serve to illustrate the general opportunities and problems that go along with the mutual recognition of judicial decisions in criminal matters.

\footnotetext{
* The authors are legal trainees in Augsburg; Frank Zimmermann is also working as a research assistant for Prof. Dr. Helmut Satzger (Ludwig-Maximilians-University Munich). We would like to express the European Judicial Training Network and particularly Ms. Hélène Cambron our sincere gratitude.

${ }^{1}$ OJ 2010 C $165 / 22$.
} 


\section{Origins and theory of the principle of mutual recognition}

Closer cooperation in criminal matters in Europe has been an issue at least since the 1970 s. $^{2}$ It has been of great importance since the foundation of the internal market in 1992 and the subsequent opening up of national borders in accordance with the Schengen Conventions. This process has given criminals the chance to operate throughout the EU without interference and beyond the control of any single Member State. Thus, there was an increasing need of national prosecution authorities to cooperate in order to be on a level playing field with international (and often organised) crime. ${ }^{3}$ At the same time, the EU Member States urged to approximate their provisions of substantive criminal law in order not to offer offenders any 'safe harbours'. These were some of the reasons which led to the creation of the former 'third pillar' of the EU in the Maastricht Treaty of 1992. With the Treaty of Amsterdam (1997), the cooperation in criminal matters and the approximation of the Member States' criminal laws even became the main issues within the 'third pillar' (which was consequently re-labelled as 'Police and Judicial Cooperation in Criminal Matters').

\section{The traditional system of mutual legal assistance}

However, this conferral of competences on the EU to take measures in certain fields of criminal law and procedure did not itself solve the problems with the struggle against cross-border crime. This was because, under the afore-mentioned circumstances, the traditional instruments of mutual legal assistance did not offer an adequate means of cooperation any longer. They were characterised by what can be called the 'request-principle': one State submits a request to another State, which is more or less free to determine whether it will comply with it or not. ${ }^{4}$ Therefore the outcome of a request under the traditional system could be rather uncertain. Additionally, practical problems such as deficient language skills and missing contact between the national authorities would frequently occur. As a result, the traditional system of cooperation is usually - though not undisputedly ${ }^{5}$ - criticised as slow and ineffective. Furthermore, there used to be numerous bilateral and multilateral international agreements defining different formal and material prerequisites for the granting of mutual legal assistance. Due to this fragmentation it was not always easy to determine which rules were to be applied when deciding on a request. To illustrate the impact that the principle of mutual recognition caused on cooperation

\footnotetext{
${ }^{2}$ In 1975, the Trevi Group was created by the European Council in order to co-ordinate the fight against terrorism.

${ }^{3}$ According to Craig/de Burca, EU LAW, 4th ed., Oxford, 2007, pp. 234 et seq., another reason was to provide the EU with a 'new' banner to enhance its legitimacy.

${ }^{4}$ COM (2000) 495 final, p. 2; H. Satzger, International and European Criminal Law, Munich, 2011 (to be published soon), § 10 margin no. 26 (with regard to the EAW).

${ }^{5}$ See K. Ambos, Transnationale Beweiserlangung - 10 Thesen zum Grünbuch der EU-Kommission „Erlangung verwertbarer Beweise in Strafsachen aus einem anderen Mitgliedstaat" (Transnational Gathering of Evidence - 10 thoughts on the Commission's Green Paper "Obtaining Evidence in Criminal Matters from One Member State to Another and Securing its Admissibility”, German), Zeitschrift für Internationale Strafrechtsdogmatik (ZIS) 2010, pp. 557 et seq., at pp. 558 et seq. (with many further references).
} 
in criminal matters within the EU, two particularly important 'traditional' conventions on cooperation with regard to evidence in criminal proceedings shall be presented in further detail. ${ }^{6}$

\section{a) The European Convention on Mutual Assistance in Criminal Matters of 1959}

The first major piece of legislation dealing with mutual assistance in criminal matters in Europe was the Council of Europe's European Convention on Mutual Assistance in Criminal Matters of 20 April 1959, ${ }^{7}$ which all EU Member States have ratified. It was designed to provide basic rules for successful cooperation in criminal matters. Since obtaining evidence is an important part of that, this so called 'Mother Convention' addresses some evidence related problems. However, mutual assistance was minimal compared to today. ${ }^{8}$

Art. 3 of this convention states that the requested Party shall execute, in the manner provided by its law, the so called 'letters rogatory' relating to a criminal matter for the purpose of procuring evidence or transmitting articles to be produced in evidence, records or documents. The Parties were allowed, however, to let the execution of letters rogatory for search and seizure depend on different preconditions, such that the offence is punishable under the law of both States (requirement of double criminality), that the offence is an extraditable one in the requested State or that the execution of the letters rogatory is consistent with the law of the requested Party (art. 5). Furthermore, assistance could be refused for many other reasons that were mainly based on political considerations - for instance if the request concerned a behaviour that the requested Party considered a military, political or fiscal offence, or if the requested Party considered the execution of the request likely to prejudice its sovereignty, security, ordre public or other essential interests (art. 2).

Although this convention was amended by an additional protocol in 1978, which aimed at facilitating legal assistance with regard to fiscal offences and was likewise ratified by all EU Member States, it took several decades until substantial advances in cooperation in criminal matters could be achieved on a multilateral European level - this time by an instrument created within the framework of the European Union. ${ }^{10}$

\footnotetext{
${ }^{6}$ The Convention Implementing the Schengen Agreement (CISA, OJ 2000 L 239/1) also deals with judicial assistance in its arts 48-53, but was largely superseded by the EU Convention of 2000.

${ }^{7}$ ETS No. 30, entered into force on 12 June 1962.

${ }^{8}$ For example, the convention addresses experts and witnesses (arts 7 et seq.). However, these provisions only deal with serving writs and securing witnesses' and experts' rights. A signatory State could not ask another one to conduct an interrogation.

${ }^{9}$ ETS No. 99, entered into force on 12 April 1982.

${ }^{10}$ A second additional protocol to the CoE's Convention of 1959 was adopted in 2001 (ETS No. 182) and entered into force on 1 February 2004. It contains similar provisions as the EU Convention of 2000, but has only been ratified by 13 EU Member States until March 2011.
} 


\section{b) The EU Convention on Mutual Assistance in Criminal Matters of 2000}

On 29 May 2000, the European Council adopted the Convention on Mutual Assistance in Criminal Matters between the Member States of the European Union $^{11}$ to provide mutual assistance in a fast and efficient manner compatible with the basic principles of the Member States' national laws. Although it was based on art. 34(2)(d) TEU-Amsterdam, this convention still followed the rules of the traditional system of cooperation. In general, it was intended to supplement (amongst others) the provisions and facilitate the application of the European Convention on Mutual Assistance in Criminal Matters of 20 April 1959, art. 1(1)(a). Its art. 1(2) further provides that more favourable agreements between the signing States shall not be affected.

The Convention concentrates on two main parts: The first part (arts 1-7) addresses formalities and procedural aspects of mutual assistance. The Member States shall execute requests as soon as possible (art. 4(2)) and shall comply with the formalities and procedures expressly indicated by the requesting State (art. 4(1)), so called forum regit actum principle.

The second part (arts 8-22) deals with specific forms of mutual assistance, like the restitution of articles obtained by criminal means to their rightful owner (art. 8), the temporary transfer of persons held in custody for purpose of investigation (art. 9) and the hearing of witnesses or experts by videoconference (art. 10) or telephone conference (art. 11). Detailed provisions for the interception of telecommunications can be found in arts 17-22.

Only one year after its adoption - and long before it actually entered into force the convention was amended by an additional protocol with regard to information on bank accounts. ${ }^{12}$

\section{The principle of mutual recognition pursuant to arts $67(3), 82(1)$ TFEU}

Since the entry into force of the Lisbon Treaty in 2010 arts 67(3) and 82(1) TFEU explicitly state that the principle of mutual recognition shall be the basis of cooperation in criminal matters. From art. 82(1) TFEU it can even be inferred that the new competences to adjust national provisions of criminal procedure in art. 82 (2) TFEU and to harmonise the Member States' substantive criminal law in selected fields according to art. 83(1) TFEU are mainly intended to serve the implementation of the recognition approach. This emphasis on the principle of mutual recognition in the new European primary law shows that this concept has become fundamental for future cooperation in criminal matters within the Union.

When it was initially being applied to the field of criminal matters, the principle of mutual recognition did not have any foundation in the European treaties. Instead

\footnotetext{
${ }^{11}$ OJ 2000 C 197/1; entered into force on 23 August 2005.

${ }^{12}$ OJ 2001 C $326 / 1$.
} 
it was merely based on political will. In 1998, during its EU Presidency, the UK Government presented this principle as a new approach to solve the problems concerning cooperation in criminal matters. ${ }^{13}$ One year later, at the European Council of Tampere, it was already regarded as the 'cornerstone' for all future developments with regard to cooperation in criminal matters. ${ }^{14} \mathrm{~A}$ further important step towards its general acceptance was the communication from the Commission to the Council and the European Parliament on 'Mutual Recognition of Final Decisions in Criminal Matters', ${ }^{15}$ which contained detailed proposals for its implementation. These political efforts finally led to a consensus on the application of the principle of mutual recognition in criminal matters. ${ }^{16}$ In 2002, the framework decision (FWD) on the European arrest warrant (EAW) ${ }^{17}$ was the first measure based on the mutual recognition approach, which was subsequently followed by many others.

However, the underlying concept is not at all a new one, but it originates from the internal market where it serves the free movement of products and persons: if a certain good is admitted to the market of one Member State, the principle of mutual recognition ensures that it will also be admitted in all the other Member States and can therefore be traded in the entire Union. This way every Member State has to recognise the other Member States' regulatory standards, even if they are lower than its own ones. In its original field of application, the principle of mutual recognition thus enhances free trade within the Union without the necessity to harmonise regulatory laws.

\section{a) The functioning of mutual recognition in criminal matters}

In general, when applied to judicial decisions in criminal matters, the principle of mutual recognition works as follows: if the judicial authorities of one Member State (issuing State) issue a particular decision with regard to a criminal proceeding, the authorities of the Member State to which this decision is directed (executing State) are obliged to execute it without further examination. Thus the admissibility of the respective measure can only be established by the issuing authority on the basis of its own domestic law, whereas the implementation of the decision is governed by the executing State's law. As a consequence, the executing authority must comply with the issuing authority's decision, no matter if a comparable measure would be admissible under its own law. Only under very limited circumstances the executing State can invoke a right, or even a duty, to refuse the execution of the foreign authority's decision: the legislative acts adopted so far indicate a narrowly confined

\footnotetext{
${ }_{13}$ Presidency Conclusion no. 39 of the European Council of Cardiff (15 and 16 June 1998), http://ec.europa.eu/ archives/european-council/index_en.htm (last visited March 2011).

${ }^{14}$ Presidency Conclusion no. 33 of the European Council of Tampere (15 and 16 October 1999),http://ec. europa.eu/archives/european-council/index_en.htm (last visited March 2011).

${ }^{15}$ COM (2000) 495 final.

${ }^{16} \mathrm{~V}$. Mitsilegas, The constitutional implications of mutual recognition in criminal matters in the EU, CMLR 43 (2006), pp. 1277 et seq., at pp. 1279 et. seq.

${ }^{17}$ OJ 2002 L $190 / 1$.
} 
and apparently exhaustive list of (mandatory or optional) reasons for non-execution. Apart from that, these instruments normally do not concede the executing authorities any further discretion. Exceptions to this rule might be derived from the ECJ case law with regard to the internal market. ${ }^{18}$ But since the only indication for the admissibility of extraordinary grounds for refusal could be seen in passages guaranteeing the respect of fundamental principles of Union law (e.g. in art. 1(3) FWD EAW), they would have to be limited to extreme cases. Thus the executing authorities do not have much leeway in the implementation of the foreign decision, whereas such wide discretion used to be normal under the traditional system of mutual legal assistance.

\section{b) General criticism of mutual recognition in criminal matters}

As a consequence, the issuing State's law of criminal procedure takes effect in the executing State's territory. One could even say that the executing State partially loses the control of the enforcement of judicial decisions in criminal proceedings in its own territory. ${ }^{19}$ Hence, traditional concepts of national sovereignty are being challenged. $^{20}$ This is, of course, a very sensitive issue - therefore it is commonly accepted that the application of the principle of mutual recognition requires mutual trust: the extraterritorial effects of decisions issued by another Member State's authorities are only acceptable to the executing State if it has confidence in the reasonableness of the issuing States' laws and their application. ${ }^{21}$ However, the assumption that a sufficient level of mutual trust has already been achieved is a questionable one. ${ }^{22}$ This can be inferred from the following considerations:

(1) Criminal proceedings usually entail serious interferences with the individual's basic rights. For instance, investigative measures for the gathering of evidence - upon which this contribution shall focus - normally go along with interferences with privacy and property rights. Apart from that, the fact of being prosecuted itself can have a severe stigmatising effect - for example, the searching of a suspect's home will usually be noticed by neighbours and discredit the concerned person. Therefore, the question of where to draw the line between the public interest of conducting a criminal investigation on the one hand, and the protection of the concerned person's fundamental rights on the other, is one that is strongly influenced by constitutional law and a society's historical, cultural and social values. ${ }^{23}$ For this

\footnotetext{
${ }^{18}$ E.g. for shortcomings that are clear and based upon information that is submitted by the issuing Member State, see A. Klip, European Criminal Law, Antwerp, 2009, pp. 344 et seq.

${ }^{19}$ S. Peers, Mutual Recognition and Criminal Law in the European Union: Has the Council Got It Wrong?, CMLR 2004, pp. 5 et seq., at p. 10; C. Burchard, Die Europäische Ermittlungsanordnung ("European Investigation Order"): Exekutorische Strafrechtsvergleichung und das Prinzip der gegenseitigen Anerkennung, in S. Beck/C. Burchard/B. Fateh-Moghadam (eds.), Strafrechtsvergleichung als Problem und Lösung, Baden-Baden, 2011, pp. 275 et seq., at pp. 283 et seq.

${ }^{20}$ Mitsilegas, CMLR 2006, p. 1282.

${ }^{21}$ COM (2000) 495 final, para. 3.1.

${ }^{22}$ V. Mitsilegas, EU Criminal Law, Oxford, 2009, p. 132, criticises the entire concept of mutual trust as 'inherently subjective and thus not amenable to judicial review'.

${ }^{23}$ Ambos, ZIS 2010, pp. 563 et seq.
} 
reason it is not surprising that before the entry into force of the Lisbon Treaty, the EU did not have an explicit competence to take harmonising measures in the field of criminal procedure and that, consequently, ${ }^{24}$ there has virtually been no harmonisation at all. ${ }^{25}$ The European Convention on Human Rights (ECHR), and in particular the fair trial principle as enshrined in its art. 6, has not produced a satisfactory approximation of criminal procedural laws in Europe either (and was not intended to do so), but only prohibits proceedings that are unfair when seen as a whole. ${ }^{26}$ Common rules for specific aspects of criminal procedure can therefore hardly be derived from the ECHR (except the ban of torture pursuant to art. 3 ECHR). But how shall the executing State's authorities have trust if they cannot be sure that the issuing State provides for similar rules in criminal proceedings and guarantees a comparable level of protection for the individual as their own legal order?

(2) At this point, another crucial aspect comes into play - legal certainty. In parallel with the principle of legality in substantive criminal law it could be argued that the severe interventions going along with criminal investigations are only acceptable if the citizens have at least the chance to foresee (by taking a look in the respective code of criminal procedure) the coercive measures they might be confronted with. Otherwise, they will not be able to inform themselves about their procedural rights and the limits of the authorities' capacities; hence an effective defence would become almost impossible. ${ }^{27}$ But according to the mutual recognition approach, a citizen can potentially be confronted with the procedural rules of 26 foreign States, all of which can theoretically take effect on the territory of his or her home country - a circumstance that Mitsilegas calls a 'journeyintotheunknown'. ${ }^{28}$ This would not cause any serious problems if the Member States' laws on criminal procedure more or less resembled each other. However, as shown above, this is not the case - even defence counsels will hardly be able to find out to what extent the respective coercive measure has been admissible.

(3) An automatic execution of judicial decisions issued in another Member State can also be problematic due to differences between the national provisions of substantive

\footnotetext{
${ }^{24}$ Also the Commission's first proposal for a harmonisation of the rights of suspects in criminal proceedings (COM [2004] 328 final) was rejected due to doubts as to the existence of a legal competence, see $M$. Fletcher/R. Löof/B. Gilmore, EU Criminal Law and Justice, Cheltenham, 2008, pp. 127 et seq.

${ }^{25}$ An exception is FWD 2002/220/JHA, OJ 2001 L 82/1. A certain indirect harmonisation has been achieved by setting up preconditions for the mutual recognition of decisions (e.g. for judgments in absentia by means of FWD 2009/299/JHA, OJ 2009 L 81/24), see J. Vogel/H. Matt, Gemeinsame Standards für Strafverfahren in der Europäischen Union (Common Standards for Criminal Proceedings in the EU, German), Strafverteidiger 2007, pp. 202 et seq., at p. 210.

${ }^{26}$ Gle $\beta$, Replies to Green Paper on Obtaining Evidence in Criminal Matters from One Member State to Another and Securing its Admissibility, pp. 3 et seq. (available at http://ec.europa.eu/justice/news/consulting_public/news_consulting_0004_en.htm, last visited January 2011).

${ }^{27}$ See also F. Zimmermann, Judicial assistance and equality of arms - to what extent can European Cooperation in Penal Matters serve as a model for the reviewed Rome Statute, in: O. Triffterer/C. Burchard/J. Vogel (eds.), The Review Conference and the Future of the International Criminal Court, Neuwied, 2010, p. 295 (with regard to the EAW).

${ }^{28}$ Mitsilegas, CMLR 2006, p. 1281;. J. Vogel/C. Burchard, in: Grützner/Pötz/Kreß (eds.), Internationale Rechtshilfe in Strafsachen, 3rd ed., Heidelberg, loose-leaf (February 2011), § 77, margin no. 37, thus have doubts as regards the compatibility with German constitutional law.
} 
criminal law. Criminalisation of social behaviour is one of the strongest interventions of government into people's lives. As the German Bundesverfassungsgericht (Federal Constitutional Court) has recently put it in its decision on the constitutionality of the Lisbon Treaty: 'It is a fundamental decision to which extent and in which areas a political community uses the means of criminal law as an instrument of social control. ${ }^{29}$ This linkage between fundamental values and criminal law can easily be illustrated by provisions concerning abortion or euthanasia - substantial differences between the national laws can be found in those fields, resulting from diverging concepts of fundamental values. However, differences also exist with regard to the general principles of criminal law and selected aspects of specific offences. ${ }^{30}$ Under the 'pure' principle of mutual recognition, a State could therefore be obliged to carry out an investigative measure ordered for an act that is not punishable under its own criminal law. This may lead to conflicts between the obligation to execute a request for assistance and deeply enrooted social and ethical values of a society.

(4) Furthermore, the automatic recognition and execution of judicial decisions based on a foreign law can also be criticised from the point of view of democratic legitimacy. The citizens of one Member State have no democratic means to influence the other 26 Member States' laws of criminal procedure. ${ }^{31}$ Nevertheless they can be subjected to those laws even if they do not leave their home country.

\section{c) Intermediate result}

The sensitivity of criminal proceedings constitutes an important difference compared to the laws framing the internal market: market regulation does not touch basic values in the way criminal proceedings do. ${ }^{32}$ Its main purpose is to balance the interests of coequal market participants, whereas criminal proceedings are characterised by the subordination of an individual to prosecution authorities. Likewise, a lack of legal certainty concerning market regulation is easier to accept because of the less serious consequences those regulations have for people's lives, compared to the effects of criminal prosecution. Furthermore, the general effect of mutual recognition in the field of market regulation differs from the one in criminal matters. Regarding the internal market, the principle of mutual recognition has a liberalising effect. It strengthens the basic freedoms as enshrined in the Union's primary law by creating an area where persons and goods can flow freely without interferences by national borders or different national regulations. However, the application of the principle of mutual recognition to criminal matters mainly ${ }^{33}$ has the opposite effect: since it serves to recognise and enforce decisions of national courts and authorities that intervene with personal freedoms it restricts the indivi-

\footnotetext{
${ }^{29}$ BVerfGE (Reports of the Federal Constitutional Court) 123, p. 267 (para. 355). The German text is also available at www.bundesverfassungsgericht.de.

${ }^{30}$ Mitsilegas (n. 22), p. 102.

${ }^{31}$ Peers, CMLR 2004, pp. 24 et seq.; Mitsilegas, CMLR 2006, pp. 1287 et seq.

${ }^{32}$ Klip (n. 18), pp. 346, 351 et seq.

33 The mere recognition of court decisions can also promote personal freedom because a ne bis in idem rule is the logical consequence, Satzger (n. 4), § 10 margin no. 64; Mitsilegas, CMLR 2006, pp. 1299 et. seq.
} 
dual's liberty instead of supporting it. ${ }^{34}$ This allows for a first (tentative) conclusion: since cooperation in criminal matters is an area quite different from the original field of application of the principle of mutual recognition, this approach certainly cannot be transferred 'one to one'. 35

\section{The interdependence of mutual recognition and harmonisation of national laws}

It has already been stated that, apart from facilitating mutual legal assistance, the approximation of the different national laws was also considered crucial for a more effective struggle against crime within the EU. However, the relation between mutual recognition on the one hand and harmonisation on the other was not always as clear: curiously, proponents and opponents of further harmonisation of national criminal laws both infer their arguments from the principle of mutual recognition. In 1998, the UK Government promoted this approach as an alternative to further harmonisation since, like in the internal market, the recognition of foreign standards was expected to make a time consuming harmonisation of differing national provisions unnecessary. ${ }^{36}$ The German Bundesverfassungsgericht also sees limited mutual recognition as a means to preserve the national criminal justice system (which it regards as closely linked to the national identity and sovereignty) from excessive harmonisation efforts by the EU. ${ }^{37}$ According to the Commission, however, mutual recognition often 'goes hand in hand with a certain degree of standardisation.' On the other hand, the Commission states that mutual recognition can, to some extent, make harmonisation unnecessary. ${ }^{38}$

As seen above, mutual trust is considered a prerogative for mutual recognition and it can only exist if there is a certain common basis in all Member States' systems of criminal justice. In this regard, two ${ }^{39}$ aspects can be distinguished. First, a certain level of approximation of the Member States' substantive criminal laws is necessary because the certainty that the behaviour would also constitute a criminal offence in its domestic law would make it easier for the requested State to execute a request for assistance. Second, the approximation of national procedural laws is a prerequisite for the development of mutual trust in transnational criminal proceedings within the EU. ${ }^{40}$ In particular, such harmonisation efforts could strengthen legal certainty and guarantee the EU citizens a minimum of procedural standards. With-

\footnotetext{
${ }^{34}$ Peers CMLR 2004, p. 24; Mitsilegas, CMLR 2006, p. 1281; S. Gleß, Zum Prinzip der gegenseitigen Anerkennung (The Principle of Mutual Recognition, German), 116 Zeitschrift für die gesamte Strafrechtswissenschaft 2004, pp. 353 et seq.; T. Pohl, Vorbehalt und Anerkennung (Reservation and Recognition, German), Baden-Baden, 2009, at pp. 75 et seq.; S. Braum, Das Prinzip gegenseitiger Anerkennung - Historische Grundlagen und Perspektiven europäischer Strafrechtsentwicklung, Goltdammers's Archiv für Strafrecht 2005, pp. 681 et seq. (at p. 688). Also see Satzger (n. 4), § 10 margin no. 25.

${ }^{35}$ For a different concept see B. Schünemann (ed.), A Programme for European Criminal Justice, Cologne, 2006.

${ }^{36}$ Council doc. $7090 / 99$, paras 7 and 8 .

${ }^{37}$ BVerfGE 113, 273 (para. 75).

${ }^{38}$ COM (2000) 495 final, para. 3.1.

${ }^{39}$ As a third level on which harmonisation is needed, Mitsilegas (n. 22, pp. 101, 102 et seq.) identifies 'the very area of law giving rise to judgements whose mutual recognition is required'.

${ }^{40}$ S. Peers, EU Justice and Home Affairs Law, 2nd ed., Oxford, 2007, p. 429; Fletcher/Löof/Gilmore (n. 24), p. 127.
} 
out harmonisation there is no basis to justify the extraterritorial effect of foreign judicial decisions which is produced by the obligation to recognise and execute them. ${ }^{41}$ In other words: the principle of mutual recognition cannot be seen as an alternative to the approximation of national laws (as in the internal market), on the contrary it requires a minimum amount of previous harmonisation. ${ }^{42}$ Therefore the new competence to adjust the Member States' laws of criminal procedure, based on art. 82(2) TFEU, is a welcome development.

A creation of minimum standards could also strengthen the democratic legitimacy of the application of the principle of mutual recognition. Regardless of whether there still is a relevant democratic deficit in the legislation of the EU, ${ }^{43}$ harmonisation measures upon which the European Parliament has decided pursuant to the ordinary legislative procedure would allow the citizens to influence the creation of supranational standards that would apply to every national measure in the field of criminal law.

\section{EU-legislation on gathering evidence based on the mutual recogni- tion approach}

\section{The framework decision on the execution of orders freezing property or evidence}

The first instrument that implemented the principle of mutual recognition in the field of obtaining evidence was the FWD on the execution in the European Union of orders freezing property and evidence of 22 July $2003 .{ }^{44}$ It addresses the need for immediate mutual recognition of orders intended to prevent the destruction, transformation, moving, transfer or disposal of evidence. ${ }^{45}$ To this purpose, it allows Member States to issue so called freezing orders to secure evidence or facilitate the subsequent confiscation of property, art. 3. The FWD thus aims to maintain pieces of evidence which are already available in one State so that they may be used by other States as well. It does not, however, provide ways for the Member States to exchange the secured pieces of evidence. For this transfer the prosecuting States still have to revert to the traditional system of mutual legal assistance as basically laid down in the conventions on mutual assistance of 1959 and 2000.

If the freezing order is transmitted correctly (as provided by art. 4), the judicial authority of the executing State is obliged to execute it without any formality and legal scrutiny (art. 5). A provision of particular relevance is art. 3(2): it abolishes the requirement of double criminality for a catalogue of 32 roughly defined categories of offences such as 'terrorism', 'sabotage', or 'computer-related crime'. As a con-

\footnotetext{
${ }^{41}$ Burchard (n. 19), p. 299, criticises the experimental character of the concept of mutual recognition.

${ }^{42}$ See Peers CMLR2004,p. 35; Zimmermann (n. 27), p. 298, 307; Similar: Fletcher/Löö/Gilmore (n. 24), p.111.

${ }^{43}$ The German Federal Constitutional Court still sees a fundamental difference between the democratic legitimacy of national parliaments and the EP, BVerfGE 123, p. 276 (paras 271 et seq.).

${ }^{44}$ OJ 2003 L 196/45.

${ }^{45}$ Recital no. 5, FWD 2008/978/JHA, OJ 2008 L 350/72.
} 
sequence, Member States cannot deny requests on the ground that the offence for which assistance is sought is not punishable under their national law as long as it falls within one of the categories contained in this so called 'positive list'. ${ }^{46}$

In close preconditions, art. 7 allows the executing State not to recognise and execute a freezing order. That is, for example, if there is an immunity or privilege under the law of the executing state that makes it impossible to execute the freezing order, art. $7(1)(b)$, or if it is instantly clear that rendering judicial assistance would infringe the ne bis in idem principle, art. $7(1)(\mathrm{c}) .{ }^{47}$ The executing state can postpone the execution if it might damage an ongoing criminal investigation or if the evidence concerned has already been subjected to a freezing order in criminal proceedings, art. 8(1)(a) and (b).

\section{The Framework Decision on the European Evidence Warrant}

As has already been pointed out, the FWD on freezing orders left the subsequent transfer of the secured evidence to the traditional, time-consuming and barely efficient system of mutual assistance. In order to fill this gap, ${ }^{48}$ the Council adopted - after long debates ${ }^{49}$ - the FWD on the European Evidence Warrant ${ }^{50}$ (EEW) for the purpose of obtaining objects, documents and data for use in criminal proceedings. Its main objective was to replace the traditional system of assistance in criminal matters and to further enhance mutual recognition in the field of gathering evidence. ${ }^{51}$ However, the scope of the FWD on the EEW is limited to pieces of evidence that already exist, art. 4 (3). Therefore, the issuing State cannot require the executing State to produce new evidence, for instance by means of interrogations or other types of hearings, bodily examinations, interception of telecommunications or covert surveillance.

Art. 11 provides that the executing authority shall recognise an EEW without any further formality and execute it in accordance with its domestic procedural rules (art. 11(2)). However, the issuing authority can request that formalities which it considers important for the further proceeding are taken into account forum regit actum principle, art. 12). The issuing authority must be satisfied that the obtaining of the objects, documents or data is necessary and proportionate, art. 7(a), and that it could obtain the respective pieces of evidence in a comparable case on its own

\footnotetext{
46 The vagueness of these categories could invite Member States to abuse the 'positive lists', Klip (n. 18), p. 353.

${ }^{47}$ Another ground for non-recognition exists if the issuing state did not use the form attached to the FWD, art. 7 (1)(a).

${ }^{48}$ Recital no. 5 of theFWD on the EEW.

${ }^{49}$ The original proposal by the Commission, COM (2003) 688 final, was discussed for more than 5 years in the Council before an agreement on the final text could be reached. On this proposal: A. Ijzerman, From the CATS Portfolio: the European Evidence Warrant, in: J. Vervaele (ed.), European Evidence Warrant, Antwerp, 2005, pp. 9 et seq.

${ }^{50}$ FWD 2008/978/JHA, OJ 2008 L 350/72; see B. Roger, Europäisierung des Strafverfahrens - oder nur der Strafverfolgung? (The Europeanisation of the Law of Criminal Procedure - or Only of Criminal Prosecution?, German), Goltdammers' Archiv für Strafrecht 2010, pp. 27 et seq.; Satzger (n. 4), § 10 margin nos 36 et seq.

${ }^{51}$ See recital no. 23.
} 
territory, art. 7(b). In conformity with the general idea underlying the recognition principle, it is thus the issuing State's duty to ensure that these requirements are met.

Similar to the FWD on freezing orders, there is an exhaustive enumeration of grounds for refusal. One of them applies, for instance, where the execution of the warrant would infringe the ne bis in idem principle, art. 13(1)(a). A Member State may also refuse to recognise an evidence warrant that relates to criminal offences which, under the law of the executing State, are regarded as having been committed wholly or for a major part within its territory, art. 13(1)(f)(i). ${ }^{52}$ The executing State shall not be allowed to deny execution on terms of double criminality, unless it is necessary to carry out a search or seizure, art. 14(1). Even in the latter case, art. 14 (2) abolishes the requirement of double criminality for 32 categories of offences. This technique, well known from other FWDs implementing the principle of mutual recognition, has caused specific problems in the case of the EEW: In 2005 the German law implementing the FWD on the EAW ${ }^{53}$ had been declared void by the Federal Constitutional Court. ${ }^{54}$ During the proceeding, the opponents of the law had (inter alia) expressed doubts as to the constitutionality of such positive lists due to their vagueness. Although the judges had not based their decision on this aspect, the German delegation feared an analogous ruling against the implementation of the FWD on the EEW and achieved an opt-out-clause for Germany in art. 23(4). Pursuant to this provision, Germany is authorised to define six especially vague categories (terrorism, computer-related crime, racism and xenophobia, sabotage, racketeering and swindling) in a separate declaration ${ }^{55}$ and refuse the execution of an EEW unless the issuing authority declares that the respective offence falls within the scope of the definition. ${ }^{56}$

The Member States have to make sure that the parties involved have legal remedies against the recognition and execution of the EEW, art. 18. This provision follows the basic line of the mutual recognition approach and distinguishes between legal remedies in the issuing and the executing State: whereas the reasons for the issuing of the EEW can only be challenged in the issuing State, the manner of its execution shall be controlled by the courts of the executing State.

\section{The initiative for a European Investigation Order (EIO)}

Mutual assistance in criminal matters will be taken a step further if the initiative of seven Member States (Belgium, Bulgaria, Estonia, Spain, Austria, Slovenia and Sweden) for an EIO is successful. If this directive comes into effect, it will (between the EU Member States) replace the European Convention of 20 April 1959 as well as the EU Convention of 29 May 2000 (art. 29(1) of the initiative). Likewise, the

\footnotetext{
${ }^{52}$ For more grounds for non-recognition see art. 13, for grounds for postponement see art. 16.

${ }^{53}$ FWD 2002/584/JHA, OJ 2002 L 190/1.

${ }^{54}$ BVerfGE 113, 273; see H. Satzger/ T. Pohl, The German Constitutional Court and the European Arrest Warrant - 'Cryptic Signals' from Karlsruhe, 4 Journal of International Criminal Justice 2006, pp. 686 et seq.

55 This declaration can be found in Council doc. 10100/08.

${ }^{56}$ Mitsilegas (n. 22), p. 127 draws the conclusion that with the EEW mutual recognition in criminal matters might have reached its limits.
} 
corresponding provisions of the FWD on the execution of freezing orders shall be substituted and the FWD on the EEW will be repealed, art. 29(2).

\section{a) General idea and scope of application}

According to art. 1 of the initiative, ${ }^{57}$ the EIO shall be a judicial decision issued by a competent authority of a Member State in order to have one or several specific investigative measures carried out in another Member State with a view to gathering evidence. Issuing authorities can be judges, courts, investigating magistrates or public prosecutors competent in the case concerned, art. 2(a)(i), as well as other authorities defined by the issuing State and acting in their capacity as an investigating authority in criminal proceedings, art. 2(a)(ii).

Pursuant to the FWDs on freezing orders and the EEW, Member States could only be required to freeze and/or hand over pieces of evidence which already existed. By contrast, the new investigation order shall henceforth cover all investigative measures except setting up a joint investigation team and the gathering of evidence within such a team. In its original version, art. 3(2) of the initiative also excluded certain forms of intercepting telecommunication; however, this restriction has been deleted during the negotiations in the Council. ${ }^{58}$

Art. 4(b) and (c) will allow issuing an investigation order also for obtaining pieces of evidence for proceedings brought by judicial or administrative authorities in respect of acts that are punishable under the national law of the issuing State by virtue of being infringements of the law. ${ }^{59}$

\section{b) Procedural questions}

From a technical point of view, the most important difference to previous international instruments is the introduction of deadlines for the recognition (30 days after the receipt of the EIO, art. 11(3)) and execution (90 days after the decision on whether to recognise the EIO, art. 11(4)). ${ }^{60}$

Like the EEW and the freezing order, the EIO has to be recognised and executed without formalities, art. 8(1). According to art. 8(2), the forum regit actum principle applies and the executing authority has to comply with the formalities and procedures expressly indicated in the EIO, unless this would be contrary to its fundamental principles of law. Under these circumstances the issuing State can also request that one or several of its authorities assist ${ }^{61}$ during the execution, art. 8(3).

\footnotetext{
${ }^{57}$ OJ 2010 C $165 / 22$.

${ }^{58}$ Council doc. 16643/10, p. 17.

${ }^{59}$ However, this will only be possible if the decision may give rise to proceedings before a court having jurisdiction, in particular, in criminal matters.

${ }^{60}$ Some delegations have suggested to include a time limit for the transfer of evidence after the execution of the EIO, Council doc. $12862 / 10$, p. 9 .

${ }^{61}$ This shall not imply any law enforcement powers, see recital 11 of the original initiative, which will - following a proposal by the Dutch delegation - probably be added to art. 8(3), see Council docs 12862/10, p. 5 and 16643/10, p. 24 .
} 
However, according to the original initiative ${ }^{62}$ the executing State may have recourse to a different investigative measure than the one indicated in the EIO if the latter does not exist under its national law, art. 9(1)(a), or if its use is restricted to a list or category of offences which does not include the one covered by the EIO, art. 9(1)(b). A particularly interesting provision can be found in art. 9(1)(c). It allows the executing State to choose a different investigative measure if it will have the same result as the one provided for in the EIO by less coercive means. This means that in this point - the initiative departs from the basic idea of the mutual recognition approach that only the issuing authority has the right to determine whether or not the requirements of a warrant are met in a specific case. However, there are good reasons for this modification of the principle because the executing authority, for which the effects of a particular measure in a specific case are better visible than for the issuing authority, is in a better position to judge the act's proportionality.

Legal remedies shall be available in accordance with national law. As provided for in the FWD on the EEW, the substantive reasons for issuing the EIO can only be challenged in the issuing State, art. 13.

\section{c) Grounds for refusal and postponement}

The executing State shall be allowed not to recognise nor execute an investigation order if there is an immunity or a privilege under its law rendering it impossible to execute the EIO, or if its execution would harm essential national security interests, art. 10(1)(a) and (b). At least with the latter provision the initiative maintains a ground for refusal of more or less political character which already existed in art. 13 (1)(g) FWD EEW. As the mutual recognition approach is intended to avoid the shortcomings of traditional mutual assistance, this may appear a bit outmoded. Another ground for refusal was originally provided for all cases where the required measure is not available in the executing State and cannot be substituted by another one that could produce a similar result, art. 10(1)(c). Finally, the executing authority can deny the execution of an EIO if it has been issued by administrative authorities pursuant to art. 4(a) and (b) and the measure would not be authorised in a similar national case. The execution of an EIO cannot be denied, however, because a similar decision would require judicial authorisation in the executing State. Neither did the original initiative allow for a double criminality test. However, during the negotiations in the Council the system of grounds for refusal has been subject to considerable changes that shall be discussed below (IV.4 and 5).

Furthermore, the executing State can postpone the recognition and execution if otherwise an ongoing criminal investigation or prosecution might be prejudiced or if the pieces of evidence are needed in other proceedings, art. 14(1).

\footnotetext{
${ }^{62}$ Pursuant to a later version, the right to choose a different measure according to art. $9(1)$ (a) and (b) should be largely excluded, see art. 9a(4), Council doc. 16643/10, pp. 24, 27 and IV.3.a) (1) below.
} 


\section{d) Specific provisions for selected types of assistance}

Arts 19-27 contain specific provisions for certain investigative measures, for example the temporary transfer of persons held in custody (arts 19,20), hearings of witnesses or experts by video or telephone conference (arts 21, 22), information on bank accounts and banking transitions as well as monitoring them (arts 23-25) and controlled deliveries (art. 26).

\section{A critical analysis of the initiative and the latest developments}

In the following paragraph, the initiative for a directive introducing the EIO shall be evaluated with a special view to its consequences for the position of suspects in criminal proceedings. The general idea behind this proposal is to set up a single legal regime for the gathering and transfer of evidence within the EU. This is not a new plan, however. The Commission already defined the elaboration of one comprehensive instrument for all forms of cooperation with regard to evidence in criminal proceedings as its long-term goal in $2003 .^{63}$ In a recently presented working programme it re-scheduled the issue for $2011^{64}$ and has now been overtaken by a group of seven Member States. Since there are currently two FWDs dealing with cooperation in evidence matters, both of which are limited to specific aspects and measures and are thus fragmentary, and since investigative measures not covered by these instruments still follow the complicated traditional system of mutual legal assistance, this initiative is certainly a reasonable step. It needs to be criticised, however, for being presented quite early ${ }^{65}$ - the implementation deadline of the FWD on the EEW has expired not earlier than on 19 January and it would have made sense to gain some experience with the functioning of this (already groundbreaking) instrument before substituting it. Apart from these general observations, a closer analysis reveals further shortcomings and inconsistencies of the proposal which ought to be addressed during the ongoing legislative procedure.

\section{Scope of application}

A first aspect that appears at least questionable is the new instrument's envisaged scope of application. It shall not only be possible to issue an EIO in criminal proceedings in the narrow sense, but also in proceedings brought by administrative and judicial authorities in respect of acts other than criminal offences. The only condition shall be that these acts constitute infringements of the law and can entail sanctions. Obviously the model for this provision was art. 5 of the FWD EEW. As a consequence, even minor wrongdoings, such as banal road traffic offences, could give rise to transnational investigative measures - even measures that seriously

\footnotetext{
${ }^{63}$ COM (2003) 688 final, p. 11.

${ }^{64}$ COM (2010) 171 final, p. 19.

${ }^{65}$ Of the same opinion: Ambos, ZIS 2010, p. 559.
} 
interfere with the individual's rights. Obviously this is problematic from the point of view of proportionality.

That an EIO can only be issued if the respective measure could also be taken by the authorities of the issuing State in an entirely national proceeding is not a convincing argument in this respect: Member States will not always agree on what is proportionate - carefully put, some of them are certainly rather 'generous' than others when it comes to investigating a breach of the law. In rather liberal countries the execution of an EIO issued for a negligible infringement might even cause constitutional problems. This is why art. 10(1)(d) provides for a ground for nonexecution when an EIO that has been issued in a non-criminal proceeding requires a measure which would not be authorised in a similar national case. Yet, even if a measure could be taken in the executing State because it is proportionate in a purely national context, this does not automatically mean that it is also a legitimate tool for cross-border investigations. They burden the suspect with organising his or her defence in at least two States with different languages and different procedural laws. Therefore, even a measure that may be adequate in a national proceeding can be disproportionate in a transnational case.

However, the discussion in the Council has not come to an end yet. An updated text proposed by the presidency in November 2010 contains an additional provision explicitly obliging the issuing authority to make sure that the issuing of an EIO is proportionate for the purpose of the proceeding. ${ }^{66}$ It does not appear entirely unlikely - and would certainly be desirable in order to prevent cases of abuse - that art. 4(b) and (c) will be further modified during the further negotiations.

\section{2. 'Patchwork Systems' and 'Forum Shopping' as dangers for defence rights}

Generally speaking, the principle of mutual recognition tends to combine different systems of criminal procedure because the required measure is ordered according to the law of the issuing Member State and executed under the law of another one. Due to the variety of procedural rules in Europe, such a 'patchwork system' can weaken the suspect's position considerably: ${ }^{67}$ if the production of evidence in the pre-trial stage is not subject to strict control in the executing State, the latter's procedural concept may nevertheless be well-balanced and fair if it guarantees essential defence rights in the trial stage. ${ }^{68}$ By contrast, the legal conditions for obtaining evidence in the issuing State may be much lower in the trial stage than in the pre-trial stage. If evidence gathered according to the rules of the executing State

\footnotetext{
${ }^{66}$ Art. 5a(1)(a), Council doc. 16643/10, p. 19. Meanwhile, the Belgian Presidency has proposed to introduce a compulsory validation procedure in order to guarantee that an EIO issued by administrative authorities respects the preconditions set out in the future directive, see Council doc. 17854/10, p. 3.

${ }^{67}$ Klip (n. 18), p. 351 speaks of 'anarchy or a "wild west" scenario, in which any piece of evidence must be admitted as long as it comes from abroad.'

${ }^{68}$ S. Gleß (Mutual Recognition, Judicial Inquiries, Due Process and Fundamental Rights, in J. Vervaele [ed.], European Evidence Warrant, Antwerp, 2006, pp. 121 et seq., at p. 124) calls this a 'specific balance in national legal systems'.
} 
was introduced in a trial in the issuing State, procedural safeguards during the pretrial stage (e.g. concerning the participation of the defence during the hearing of a witness) would be bypassed. ${ }^{69}$ In such a case, there are basically two possibilities: either the piece of evidence gathered in the executing State is declared inadmissible - then the issuing of the EIO would finally have been in vain; or it is admitted then the suspect would lose essential guarantees in the pre-trial phase.

This dilemma ${ }^{70}$ is largely avoided by the initiative for the EIO. Firstly, it does not provide for an obligation of the issuing State to admit the requested evidence in trial. This is not self-evident because the Commission has already made several attempts to introduce such a rule ${ }^{71}$ (which were rarely appreciated ${ }^{72}$ and criticised by most commentators ${ }^{73}$ ). Since the initiative does not follow this approach, the courts of the issuing State will not be compelled to use the evidence obtained by virtue of an EIO in trial and it will remain their decision to what extent it shall be admissible. Consequently, infringements of procedural rules during the pre-trial stage can still be remedied. Secondly, the forum regit actum principle, enshrined in art. $8(2)$ and (3) of the initiative, gives the issuing authority a certain influence on the manner in which the EIO is executed. Therefore, it can make sure that procedural safeguards that are essential for the admissibility of evidence in the issuing State are respected during the execution of the EIO. This way, the proceeding basically follows the rules of the issuing State and all safeguards for a fair trial under its domestic law are maintained. Nevertheless some reservations need to be made: to a certain extent the forum regit actum rule obliges the executing authorities to apply foreign law. This circumstance can be problematic ${ }^{74}$ from the point of view of democratic legitimacy and also due to the fact that the officials in charge, usually, would not be sufficiently educated in the issuing State's law. Furthermore, the compliance with formalities and procedures indicated by the issuing authority is always subject to the condition that this is not contrary to the fundamental principles of law of the executing State. Hence it remains possible that evidence

\footnotetext{
${ }^{69}$ H. Satzger, The Future of European Criminal Law between Harmonisation, Mutual Recognition and Alternative Solutions, 1 Journal of European Criminal Law 2006, pp. 27 et seq., at p. 36; Zimmermann (n. 27), pp. 297 et seq.

${ }^{70}$ Burchard (n. 19), p. 280.

${ }^{71}$ See the Green Paper on the Establishment of a European Public Prosecutor, COM (2001) 715 final, and the Green Paper on Obtaining Evidence in Criminal Matters from One Member State to Another and Securing its Admissibility, COM (2009) 624 final.

${ }^{72}$ See for example the comment of the Deutscher Richterbund (Association of German Judges), available at http://www.drb.de/cms/index.php?id=658\&amp;L=0 (last visited March 2011).

${ }^{73} \mathrm{~J}$. Spencer, The Green Paper on obtaining evidence from one Member State to another and securing its admissibility: the Reaction of one British Lawyer, Zeitschrift für Internationale Strafrechtsdogmatik 2010, 602 et seq., at pp. 604 et seq.; L.Bachmeier Winter, European investigation order for obtaining evidence in the criminal proceedings, Zeitschrift für Internationale Strafrechtsdogmatik (ZIS) 2010, pp. 580 et seq., at p. 588; B. Schünemann/ B. Roger, Stellungnahme zum Grünbuch der EU-Kommission: "Erlangung verwertbarer Beweise in Strafsachen aus einem anderen Mitgliedstaat“ (Opinion to the EU Commission's Green Paper: „obtaining evidence from one Member State to another and securing its admissibility“, German), Zeitschrift für Internationale Strafrechtsdogmatik 2010,92

${ }^{74}$ S. Gleß, Beweisrechtsgrundsätze einer grenzüberschreitenden Strafverfolgung, Baden-Baden, 2006, pp. 168, 114; Ambos, ZIS 2010, p. 561.
} 
produced by virtue of an EIO suffers from procedural deficiencies so that its admissibility in trial can be doubtable.

Furthermore, the risk remains that the issuing authority might try to circumvent defence rights by sending an EIO to a Member State where the rules for collecting evidence are less strict than in its own legal order. Such a 'forum shopping' would not necessarily produce inadmissible evidence because, depending on the issuing State's law of criminal procedure, the respective pieces of evidence might nevertheless be used in trial. In the FWD on the EEW, this problem was tackled in art. 7 (b), explicitly obliging the issuing authority to make sure that the respective pieces of evidence could be obtained in a similar and purely national proceeding. ${ }^{75}$ By contrast, a comparable provision was missing in the original initiative for an EIO. Although some have voiced the opinion that this did not mean any relevant change because the issuing authority would have to check this requirement anyway, ${ }^{76}$ it must be stated that in the sensitive field of criminal procedure, it should simply not be taken for granted that basic rules are always respected. Thus it would be a welcome step if the presidency's proposal to insert an additional art. $5 \mathrm{a}-$ which is comparable to art. 7(b) FWD EEW - was adopted. ${ }^{77}$

\section{Irrelevance of requirements and restrictions in the executing state}

Although the initiative for an EIO seeks to avoid the creation of 'patchwork systems', it must nonetheless be said that this instrument would make specific requirements and restrictions of coercive measures in the executing State irrelevant. Examples revealing the intricacies which may arise from that circumstance can easily be found.

\section{a) Specific requirements of coercive measures}

(1) Many procedural systems only allow certain coercive measures if the crime that shall be investigated falls under a special category or list of offences. This can be seen as a specification of the general proportionality requirement because it ensures that measures which particularly interfere with the suspect's rights will only be used in the case of serious breaches of the law. But when a measure that is admissible for all kinds of offences under the law of the issuing state is ordered in an EIO, the executing State would in principle have to carry it out - even though a comparable action was restricted by its own law to a category or list of offences which does not include the one in question. Under these circumstances, art. 9(1)(b) of the original initiative therefore allowed the executing authority to have recourse to a different investigative measure. If no adequate alternative is available, the executing State should be able to refuse to recognise and execute the EIO pursuant to art. 10(1)(c). In the latest version of the text, this possibility has unfortunately been limited and

\footnotetext{
${ }^{75}$ Gleß (n. 74), p. 169.

${ }^{76}$ Bachmeier Winter, ZIS 2010, 584.

77 This was also claimed by the Finnish delegation, Council doc. 12862/10, p. 6.
} 
shall no longer apply to all kinds of investigative measures. ${ }^{78}$ Apparently this was the 'prize' for the introduction of other grounds for refusal (see IV.4 and 5 below). However, there is no good reason for this restriction and the solution in the original initiative appeared preferable.

(2) Several legal orders stipulate that selected coercive measures may only be carried out upon a warrant issued by a judge or a court. This allows for a preliminary impartial control and thus also helps to guarantee the proportionality of measures required by the prosecution authorities. Casting a look at art. 1(1) of the initiative, defining the EIO as a 'judicial decision', one might think that problems with this requirement cannot occur. The German version - which like all versions existing in the other official languages must be taken into account ${ }^{79}$ - even uses the word 'gerichtlich' (meaning 'by a court'). Consequently, the EIO seems to cover only measures that have been ordered by a judge. However, art. 2(1)(a) of the proposal explicitly attributes to investigating magistrates, public prosecutors (i) and some other authorities (ii) the competence to issue an EIO. Since art. 1(1) only gives the general definition of the EIO and art. 2(1) deals more specifically with the issuing authorities, the latter provision must be regarded as decisive; the clear German wording of art. 1(1) is obviously due to a bad translation. This means that an EIO, issued by whatever investigating authority, can oblige the executing authority to take measures which, pursuant to its domestic law, usually require a warrant by a judge. Considering that this requirement is meant to guarantee the legality, impartiality and proportionality of serious interferences with fundamental rights, this is a fairly problematic feature of the proposed instrument. ${ }^{80}$ Until now, the Council delegations do not seem to have entirely realised that this would significantly weaken the suspect's position compared to a national proceeding in the executing State: during the discussions of the initiative they only expressed the wish that art. 2 (1)(a)(ii) - allowing 'other judicial authorities' to issue an EIO - be further clarified ${ }^{81}$ and a questionnaire was distributed in order to collect additional information on the kind of authorities that might fall under art. 2(1)(a)(ii) and on the types of measures they could order. ${ }^{82}$ Therefore the assumption does not appear too pessimistic that the requirement of a warrant by a judge might lose a lot of its weight in the future.

\section{b) Restrictions of coercive measures}

Likewise, the domestic law of the executing State can provide for special restrictions of coercive measures. In Germany, for instance, a seizure is not permissible if the respective assets are kept by persons who have the right to refuse to testify in criminal proceedings, § 97(1), read in conjunction with § 52(1) StPO (German

\footnotetext{
${ }^{78}$ See art. 9a(3) and (4) as proposed in Council doc. 16643/10.

${ }^{79}$ See, e. g. ECJ 17.10.1996, case C-64/95 (Konservenfabrik Lubella Friedrich Büker GmbH \& Co KG v. Hauptzollamt Cottbus), [1996] ECR I-5105, margin no. 17 with further references.

${ }^{80}$ Of the same opinion: Bachmeier Winter, ZIS 2010, p. 587; Vogel/Burchard (n. 28), § 77, margin no. 37.

${ }^{81}$ Council doc. 12201/10, p. 7.

82 The answers to this questionnaire can be found in Council doc. 13049/10.
} 
Code of Criminal Procedure). This is a field of criminal procedure which has not been harmonised at all and, consequently, national rules differ considerably. A provision in the context of hearings by videoconference reveals that the drafters of the initiative for an EIO have been well aware of this circumstance. Art. 21(9) obliges the Member States to ensure that witnesses and experts who are on their territory and shall be interrogated by a foreign authority in a videoconference pursuant to art. 21(1) will have the same right to refuse to testify as if the hearing took place in a national procedure. In other words, these persons will enjoy a double protection and can invoke rights not to testify according to both, the issuing and the executing State's law.

However, there is nothing equivalent to this important provision for seizure orders. This can lead to delicate conflicts for the executing authorities that can be illustrated by the following examples: according to the German law of criminal procedure, parents-in-law can refuse to give evidence in a criminal proceeding even after their child and the defendant have been divorced, § 52(1) No. 3 StPO, read in conjunction with $\S 1590(2)$ BGB (German Civil Code). Because of this, it is also inadmissible to seize evidence at their home. If another Member State does not provide for a similar restriction of seizure orders and demands that German authorities seize evidence from the defendant's ex-parents-in-law, they would have to comply with this investigation order. As a result, this instrument will make it easier to collect evidence against the suspect and his or her procedural position will be weakened. Apart from this specific problem with the German law, much more striking cases can be constructed: same sex marriages and homosexual partnerships, for instance, are not recognised in all EU Member States. If one of these States issues an EIO aiming at the seizure of evidence from the suspect's homosexual partner, any other Member State will be compelled to execute it - notwithstanding its own liberal legislation. Naturally, similar problems could arise with regard to objects that the suspected person has entrusted to his or her lawyer, doctor or priest.

A solution could be found in art. 1(3). According to this provision, the (proposed) directive on the EIO 'shall not have the effect of modifying the obligation to respect the fundamental rights and legal principles as enshrined in Article 6 of the Treaty on European Union [...]. This directive shall likewise not have the effect of requiring Member States to take any measures which conflict with their constitutional rules relating to freedom of association, freedom of the press and freedom of expression in other media'. Yet every coercive measure interferes with the suspect's fundamental rights. If this clause shall not completely undermine the idea of the EIO, it must therefore be construed narrowly, so that only serious conflicts with constitutional rights can suspend the obligation to execute an EIO. ${ }^{83}$ But would, for example, a seizure from the defendant's doctor always cause a serious conflict with the funda-

\footnotetext{
${ }^{83}$ Also sceptical as regards the use of general human rights reservations: M. Kaiafa-Gbandi, Aktuelle Strafrechtsentwicklungen in der EU und rechtsstaatliche Defizite (Recent Developments in Criminal Law in the EU and Rule-ofLaw Deficits, German), Zeitschrift für internationale Strafrechtsdogmatik 2006, p. 528. A shorter English version can be found in Schünemann (ed.), A Programme for European Criminal Justice, Cologne 2006, pp. 317 et seq.
} 
mental right to privacy? ${ }^{84}$ Likewise it would not be clear under which conditions a seizure from the suspected person's lawyer violates the fundamental right to a fair trial. $^{85}$

\section{c) Intermediate result}

The preceding paragraphs have revealed that the initiative for an EIO risks undermining the suspect's position in transnational criminal proceedings. Of course it is to a certain extent part of the rationale underlying the mutual recognition approach that only the prerequisites of the issuing State's law need to be met in order to have a measure carried out in another Member State. ${ }^{86}$ Nevertheless the fact that always the legal order with the less strict requirements for coercive measures will prevail is a worrying one. ${ }^{87}$ Therefore the efforts to insert an additional ground for refusal or at least to extend the list of immunities (see 5.a) below) are certainly worthy of consideration.

\section{The double criminality requirement}

\section{a) Far-reaching abolition in the original initiative}

The general part of the initiative, establishing rules for all types of investigative measures, did originally not allow for a double criminality test. ${ }^{88}$ On the contrary, the fact that the double criminality requirement was explicitly maintained - under limited circumstances - for investigation orders with regard to information on bank accounts in art. 23(5) ${ }^{89}$ - illustrated that this prerequisite should be abolished for all other types of evidence. Thus the executing State would have had to comply with an EIO even though the act for which assistance was sought was not a criminal offence under its national law.

\section{b) Comparison with previous instruments}

In the first part of this study it has already been pointed out that the obligation to take investigative measures although the respective behaviour is not a criminal offence in the executing State can be very problematic. Therefore, the abolition of the double criminality requirement is one of the most controversial facets of the principle of mutual recognition. It must be borne in mind, however, that double criminality used to be a prerequisite mainly in the field of extradition law. The European Convention on Mutual Legal Assistance from 1959, for instance, does not

\footnotetext{
${ }^{84}$ Art. 6(3) TEU, read in conjunction with art. 8(1) ECHR.

${ }^{85}$ Art. 6(3) TEU, read in conjunction with art. 6(1) ECHR.

${ }^{86}$ See supra II.2.a).

${ }^{87}$ See - in the context of the EAW - Kaiafa-Gbandi (n. 83), p. 326.

${ }^{88}$ Only art. 10(1)(c), read in conjunction with art. 9(1)(b) could have been (but was clearly not intended to be) read in this sense (see also the concerns raised by the Dutch delegation, Council doc. 12862/10, p. 7).

${ }^{89}$ A further exception could be seen in art. 27(1), pursuant to which an EIO concerning the gathering of evidence in real time continuously and over a certain period of time could be rejected if the execution of the measure would not be authorised in a similar national case.
} 
provide for a general double criminality requirement, but its art. 5(1)(a) merely allows the signatory States to make the execution of letters rogatory for search and seizure of property dependent on the double criminality of the respective act. Only a few States (e.g. Austria, Estonia and Hungary) have neglected this clause and have made a reservation introducing a general requirement of double criminality. ${ }^{90}$ As has been shown before, the FWD on the EEW went one step further and abolished the double criminality requirement even for warrants concerning the search and seizure of property, as long as the offence was included in the so called 'positive list'.

\section{c) Implications for the foreseeability of investigative measures}

At this point, the German position with respect to the 'positive list' in the FWD on the EEW must be recalled. Since Germany had declared an opt-out for six particularly vague categories of offences included in the positive list, the general abolition of the double criminality requirement envisaged by the original initiative almost appeared as a political affront. Much more regrettable, however, would have been the implications of this step in terms of legal certainty: no citizen of the Union can know all criminal laws of all Member States. Consequently a situation can occur in which an act deemed legal by a citizen is a criminal offence in one of the Member States. So far one might argue that this is not a characteristic of EU law, but rather a 'normal' situation because the substantive criminal laws of all States in the world differ considerably. But what is special within the EU is that its Member States have the possibility to enforce their criminal laws outside their territory. ${ }^{91}$ Therefore citizens could have been subjected to investigative measures although they were not aware that their behaviour was punishable in at least one Member State. ${ }^{92}$ What made things even worse was that, pursuant to art. $4(\mathrm{~b})$ of the proposal, it shall be possible to issue an EIO in certain administrative proceedings - if it is already difficult for a citizen to know the other Member States' criminal laws, it is entirely impossible to be aware of all provisions whose infringement can entail administrative sanctions.

\section{d) Discussions in the Council and possible solutions}

In the beginning of the debate in the Council, the presidency was reluctant towards some delegations' wish to maintain the double criminality requirement and estimated its 'reintroduction [...] a step backwards as regards to the current framework of mutual legal assistance as well as in the progressive implementation of the principle of mutual recognition. ${ }^{, 93}$ However, the problems in terms of foreseeability, and presumably also the particular situation in Germany, have obviously led to a

\footnotetext{
${ }^{90}$ All reservations and declarations are available at http://www.conventions.coe.int (last visited March 2011).

${ }^{91}$ Supra II.2.b).

92 In its judgment of 03.05.2007, case C-303/05 (Advocaten voor de Wereld), [2007] ECR I-3633, the European Court of Justice did not take into account this transnational dimension of the principle of legality, see Satzger (n. 4), § 10 margin no. 33.

${ }_{93}$ Council doc. 12201/10, p.12.
} 
change of mind. On 29 October 2010 the presidency proposed to distinguish several categories of investigative measures according to their intrusive or coercive nature and admitted that at least with regard to some measures ' $[t]$ he issue of double criminality should require further discussion'. ${ }^{94}$ In the latest version of the text, this approach can be found in art. $9 \mathrm{a}$. It (re)allows a double criminality test for almost all investigative measures of coercive character. ${ }^{95}$ Yet, with regard to some measures (searches and seizures, body searches, the taking of blood or DNA samples, psychiatric medical examinations, hearings on a compulsory basis and the temporary transfer of persons held in custody) the offence categories of art. 2(2) FWD EAW (the 'positive list') shall under no circumstances be subject to verification of double criminality. Of course, one can criticise the details of this proposal; the technique of 'positive lists', for instance, is questionable itself (see II.2). But in gerneral, the idea to distinguish between measures of less and more coersive character and to provide additional grounds for refusal for the second group certainly constitutes a major advance compared to the original text of the initiative.

Irrespective of the outcome of this debate an additional measure should be taken into consideration: The most important case in which the problem of foreseeability arises is if the act that the issuing State wants to prosecute has exclusively taken place on the territory of the executing State: then the suspect frequently does not have any reason to expect criminal liability. This is why many conventions in the field of legal assistance and even instruments implementing the principle of mutual recognition contain a 'territoriality reservation' allowing to refuse the execution of a request if the respective act has taken place within the territory of the executing State. ${ }^{96}$ Such a ground for refusal which would help to ensure the foreseeability of criminal prosecution ${ }^{97}$ is missing in art. 10 of the initiative. In the long term, however, only additional harmonisation of national substantive criminal law appears as a satisfactory perspective. ${ }^{98}$

\section{Additional grounds for refusal?}

Apart from the question of the necessity of a (limited) double criminality requirement or a 'territoriality reservation', there is an ongoing discussion in the Council on the insertion of further grounds for refusal. ${ }^{99}$ Some delegations - among them the German one - have even stipulated to introduce a wide, general ground for

\footnotetext{
${ }_{94}$ Council doc. $15531 / 10$, p. 3 et seq. In favour of the double criminality requirement at least for searches and seizures also Ambos, ZIS 2010, p. 560.

${ }_{95}$ Council doc. 16643/10 (see also the alternative proposal for art. 9 a in annex 2). For some measures - e. g. the interception of telecommunications - an optional ground for refusal is introduced if the respective measure would not have been authorised in a similar domestic case. De facto this also allows a double criminality test.

${ }^{96}$ See, e. g., art. 4 no. 7(a) FWD EAW and art. 13(1)(f)(i) FWD EEW (supra III.2).

${ }^{97}$ Also the German Constitutional Court underlined that the territoriality reservation served the principle of legal certainty in the context of the EAW, see BVerfGE 113, p. 302.

${ }^{98}$ Yet, this harmonisation must respect basic guidelines such as the principles of proportionality, legality, subsidiarity and coherence, see European Criminal Policy Initiative, A Manifesto on European Criminal Policy (www.crimpol.eu, last visited March 2011).

${ }^{99}$ For an overview see Council doc. 12862/10, pp. 12 et seq.
} 
cases where the executing authority could not take the required measure in a national proceeding. Since this proposal is somewhat contradictory to the idea of mutual recognition, it has - not surprisingly - been rejected, and indeed it appears a more convincing solution to add some clearly shaped grounds for non-execution of an EIO. ${ }^{100}$ Two proposals that merit a closer analysis are the following:

\section{a) Violation of human rights and proportionality}

The delegations of Germany and the United Kingdom have expressed a wish to add grounds for refusal for constellations where the executing State fears a violation of human rights or has doubts regarding the proportionality of the required measure. ${ }^{101}$ In the latter case, art. $9(1)$ (c) of the initiative leaves the executing State a certain discretion as regards the choice of the measure to be taken. But given the problem that an EIO might have to be recognised even if the required investigative measure is inadmissible according to the executing State's domestic law (e.g. a seizure from the suspected person's lawyer ${ }^{102}$ ), at least the wish for a human rights reservation is understandable. ${ }^{103}$ However, the presidency's reaction allows for the conclusion that the insertion of an additional ground for refusal is not a very realistic option. ${ }^{104}$ Instead, it has suggested to further develop art. 10(1)(a) of the original initiative, which allows to reject an EIO where its execution is impossible due to an immunity or a privilege. ${ }^{105}$ Since it appears questionable whether really all problematic constellations (see, for instance, IV.3.b) above) could be dealt with like this, a possible solution for sceptical Member States could be to transform the European ordre public clause in art. 1(3) into a ground for refusal. This was done by several States in the case of the EAW ${ }^{106}$ and not disapproved by the Commission. ${ }^{107}$

\section{b) Insufficient solution for ne bis in idem cases}

Finally, another ground for refusal should be included in art. 10 for cases where the execution of the EIO would conflict with the principle of ne bis in idem as enshrined in art. 50 CFREU and art. 54 CISA. ${ }^{108}$ The possibility to postpone the execution of an EIO if it prejudices an ongoing proceeding in the executing State is not sufficient: if the trial in the executing State concerned the same offence (i.e. the same material $\mathrm{act}^{109}$ ) and has been finally disposed of, the defendant may not be

\footnotetext{
${ }^{100}$ Council doc. $15531 / 10$, p. 5.

101 Council doc. 12862/10, pp. 6 et seq. and Council doc. 12201/10, p. 12.

102 Supra IV.3.b).

${ }^{103}$ See also Bachmeier Winter, ZIS 2010, p. 585: human rights reservation as necessary compensation for the abolition of the double criminality test.

${ }^{104}$ Council doc. $12201 / 10$, p. 12 . As a compromise, the presidency later proposed to provide a possibility for the executing authority to initiate direct communication with the issuing authority, see Council doc. 16643/10, p. 5 .

105 Council doc. 15531/10, p. 5; see also Ambos, ZIS 2010, p. 563.

${ }^{106}$ See, for instance, $\$ 73$ of the German 'Gesetz über die Internationale Rechtshilfe in Strafsachen' (Law on Mutual Legal Assistance in Criminal Matters).

107 COM (2006) 8 final, p. 5.

${ }^{108}$ This has also been claimed by several delegations, see Council doc. $12862 / 10$, p. 8 ,

${ }^{109}$ European Court of Justice (ECJ) 09.03.2006, case 436/06 (van Esbroeck), [2006] ECR I-2333, margin no. 36.
} 
prosecuted again in the issuing State (art. 54 CISA). Nevertheless the reason for a postponement ('ongoing criminal investigation' in the executing State) would no longer exist and the EIO would have to be executed pursuant to art. 14(2), unless the issuing State decides to withdraw it. In order to avoid this needless formality and to clarify that the ne bis in idem rule applies, it would be desirable to allow the executing State not to comply with the EIO. ${ }^{110}$

\section{Conclusion}

The initiative for an EIO is intended to mark an important step towards the creation of an area of freedom, security and justice. Indeed the introduction of a comprehensive instrument for all types of evidence does make sense and the draft shows up some promising tendencies - especially the forum regit actum principle, the right to choose a less coercive measure than the one covered by the EIO and the 'double protection clause' for videoconferences. Nevertheless, this study has shown that the initiative still suffers from serious shortcomings. On the long run, the obligation to carry out investigative measures that are not available in a domestic criminal proceeding is likely to cause mistrust rather than to promote the creation of a single judicial area. As has been stated in the first part of this contribution, this dilemma can only be overcome by a far-reaching harmonisation - also in the field of criminal procedure. The measures taken so far, in particular the new directive on the right to interpretation and translation in criminal proceedings, ${ }^{111}$ and the proposal for another one on the right to information in criminal proceedings, ${ }^{112}$ are certainly first steps into the right direction, but they cannot be more than a starting point. Also the further instruments specified in the 'Roadmap for Strengthening Procedural Rights of Suspected or Accused Persons in Criminal Proceedings ${ }^{113}$ would not solve most of the problems brought about by the EIO. Taking this into account, the European institutions are trying to put the cart before the horse if they seek to further implement the principle of mutual recognition, rather than first approximating the Member States' procedural and substantive criminal laws.

\footnotetext{
110 The revised text of the initiative (Council doc. 16643/10, p. 28) indeed provides for such an optional ground for refusal.

${ }^{111} \operatorname{COM}(2010) 82$ final.

112 COM (2010) 392 final.

113 OJ 2009 C 295/1.
} 